Article

\title{
Shelling of Growth Rings at Softwood Surfaces Exposed to Natural Weathering
}

\author{
Lukie H. Leung ${ }^{1}$ and Philip D. Evans ${ }^{1,2, *}$ \\ 1 Department of Wood Science, Faculty of Forestry, University of British Columbia, \\ Vancouver, BC V6T 1Z4, Canada; mrlukieleung@gmail.com \\ 2 Department of Applied Mathematics, The Australian National University, Canberra, ACT 0200, Australia \\ * Correspondence: phil.evans@ubc.ca; Tel.: +1-604-822-0517; Fax: +1-604-822-9159
}

Received: 13 August 2020; Accepted: 2 September 2020; Published: 5 September 2020

\begin{abstract}
Shelling is the delamination of growth rings and the projection of woody tissue from wood surfaces. Shelling disrupts coatings and makes refinishing difficult, and a better understanding of the phenomenon is needed to help alleviate its unwanted effects. We tested whether confocal profilometry could quantify shelling in flat-faced and profiled-faced western larch deckboards exposed to natural weathering and examined the effects of growth-ring orientation and angle on shelling. Confocal profilometry was able to quantify shelling in both deckboard types. Shelling developed at the surface of flat-faced deckboards oriented pith-side-up, whereas it was absent from boards oriented bark-side-up. We found an inverse correlation between the height of shelled growth rings and the angle of growth rings to the surface of flat-faced boards. Shelling occurred in profiled-faced boards oriented pith-side-up due to the delamination of growth ring tips and projection of latewood from wood surfaces. A superficially similar although less pronounced phenomenon was seen in profiled-faced boards oriented bark-side-up. The shelling of profiled-faced boards oriented pith-side-up created lanceolate-shaped slivers of latewood that projected from the peaks of profiles. Some of these latewood tips were sharp and, for this reason, we suggest that profiled-faced western larch deckboards should always be oriented bark-side-up rather than pith-side-up.
\end{abstract}

Keywords: shelling; western larch; confocal profilometry; profiling; growth rings; latewood; earlywood; pith-side-up; bark-side-up; natural weathering

\section{Introduction}

Wood that is exposed outdoors is subject to surface degradation by solar radiation (U.V. and visible light), water, heat, environmental pollutants, and mould [1]. The most obvious manifestation of such degradation is the greying of wood exposed outdoors [2]. Another highly visible effect of "weathering" is the surface cracking (checking) of wood [3]. Checks develop when moisture-induced surface stresses exceed the tensile strength of wood perpendicular to the grain [4]. The severity of checking depends, in part, on the orientation of growth rings to wood surfaces exposed to the weather. For example, checking is less severe in coniferous wood (softwood) whose growth ring are perpendicular to the exposed surface (radial or quarter-sawn boards) when compared to wood whose growth rings are mainly parallel to the surface (tangential or flat-sawn boards) [5]. Checks in quarter-sawn softwoods often develop at the interface between denser bands of summer wood (latewood) and lower density springwood (earlywood) [6]. In flat-sawn softwoods, checks develop in and propagate radially into wood via rays [4]. Flat-sawn wooden boards can be classified into ones where growth rings either curve away from, or curve towards, their upper wide surface [7] (Figure 1). These boards are commonly known as bark-side-up and pith-side-up boards, respectively [7] (Figure 1). The checking 
of wood during exposure to the weather is less pronounced in wooden boards that are oriented pith-side-up [5,8].
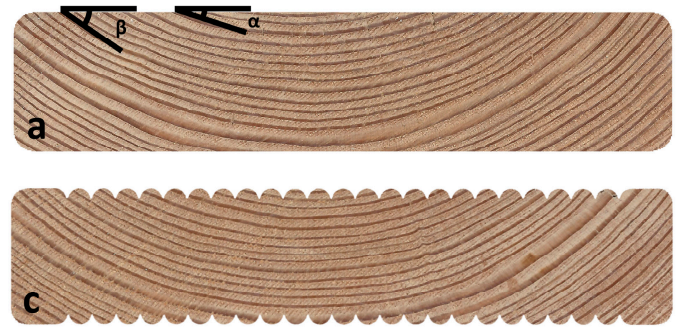
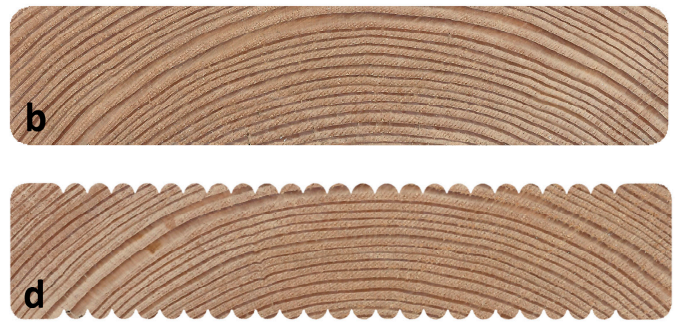

Figure 1. Orientation of growth rings to the upper exposed surface of flat-sawn (tangential) western larch deckboards. The darker bands within growth rings are latewood and the lighter bands are earlywood: (a) flat board with growth rings that curve towards the exposed upper surface. These are known as pith-side-up boards. Growth rings can make shallow $(\alpha)$ or high $(\beta)$ angles to the exposed upper surface; (b) flat board with growth rings that curve away from the exposed upper surface. These are known as bark-side-up boards; (c) profiled pith-side-up board; and, (d) profiled bark-side-up board.

In addition to checking, another less commonly known defect, shelling or loosened grain, develops at wood surfaces, especially those that are exposed to the weather [7,9-11]. Shelling occurs when mechanical or moisture-induced stresses at the surface of flat-sawn boards are sufficiently large to cause delamination of growth rings at the boundary between latewood and earlywood $[9,10]$. Such delamination of growth rings results in the projection of latewood above the surface of adjacent earlywood. Two forms of shelling have been observed at flat-sawn (tangential) surfaces that result from either the separation of tips or edges of latewood from earlywood, respectively $[9,10]$. Shelling mainly develops at the surface of boards oriented pith-side-up. It can also occur beneath opaque coatings and disrupt paint films on siding (cladding), and this is one of the reasons why wooden siding is fixed to building with growth rings oriented bark-side facing outwards $[10,11]$. Shelling, particularly shelled tips of latewood, can create sharp splinters that protrude from the surface of wood. These splinters are objectionable and dangerous according to Koehler [9], particularly when they occur at the surface of deckboards that people walk on. Shelling also makes refinishing and cleaning of wood surfaces difficult $[9,10]$. Shelling is most pronounced in softwoods with a pronounced difference in cell wall thickness between latewood and earlywood, for example, species, such as southern pine (Pinus spp.), larch (Larix spp.), and Douglas fir (Pseudotsuga menziesii (Mirb.) Franco) $[9,10,12]$, but it has also been observed in hardwood with relatively uniform structure, such as yellow poplar (Liriodendron tulipfera L.) [10]. These wood species are very important commercially. Furthermore, the wood products that are negatively affected by shelling such as decking and siding are especially important. For example, the market for wooden decking and siding in the USA had a combined value in 2018 of $\sim$ US 2.8 billion, and each year over 300 million square feet $\left(\sim 28\right.$ million $\left.\mathrm{m}^{2}\right)$ of wood siding is installed on houses in the USA $[13,14]$. However, wooden siding and decking are losing market share, because they require more maintenance particularly refinishing and cleaning than products made from alternative materials, such as plastic and composites (wood-plastic and wood-fibre cement composites) $[13,14]$. Hence, there is a need to better understand and develop solutions to problems such as shelling that reduce coating durability and increase the frequency of refinishing of wood products used for siding and decking.

Our understanding of shelling is based on a small number of studies $[7,9,10]$, but, unlike grain raising, which was until recently a similarly neglected surface phenomenon that affects the performance of coatings on wood, no method has been developed to quantify shelling at weathered wood surfaces. Grain raising was first quantified using stylus profilometry [15], and recent studies have used non-contact profilometry to quantify and image grain raising [16,17], and examine the shape recovery of earlywood and latewood beneath machined and painted radiata pine (Pinus radiata $\mathrm{D}$. Don) 
panels soaked in water $[18,19]$. The latter research suggests that the current generation of non-contact profilometers will be able to quantify shelling at weathered wood surfaces and provide insights into its origins. We test this hypothesis in this paper. We use confocal profilometry and macro-photography to quantify and image shelling of flat-faced western larch (Larix occidentalis Nutt.) deckboards (hereafter called flat deckboards) exposed to natural weathering for seven months. Profilometry and scanning electron microscopy were also used to image shelling of flat alkaline copper quaternary (ACQ) treated Douglas fir, western hemlock (Tsuga heterophylla (Raf.) Sarg.), and white spruce (Picea glauca (Moench) Voss) deckboards exposed to the weather for 18 months. We extend our observations of shelling of flat deckboards to include profiled-faced larch deckboards (hereafter called profiled deckboards) that were exposed to the weather because there are no reports in the literature on the shelling of profiled deckboards, even though profiling is widely used in Australia, Europe, Japan, and New Zealand to reduce the negative effects of checking on the appearance of deckboards exposed outdoors [20,21].

\section{Materials and Methods}

\subsection{Preparation and Weathering of Larch Deckboards}

Six flat-sawn, J-grade, kiln-dried, and dressed western larch boards cut from trees growing in the interior of British Columbia, BC, Canada, and measuring $38 \times 140 \times 3658 \mathrm{~mm}^{3}$, were donated by Tolko's Lavington Planer Mill Ltd. (6200 Jeffers Drive, Lavington, British Columbia, BC, Canada). Each parent board was cross-cut using a pendulum saw (Stromab ps 50/f, Campagnola Emilia, Italy) to produce six samples, each $600 \mathrm{~mm}$ in length. Samples were then randomly assigned to one of five deckboard profiles or the flat control, Table 1. Sample boards were then profiled on both sides using a moulding machine (Weinig Powermat 700, Michael Weinig Inc., Mooresville, NC, USA) equipped with a $125 \mathrm{~mm}$ diameter, two-wing, cylindrical rotary cutter head (Great-Loc SG Positive Clamping Universal Tool System, Great Lakes Custom Tool Mfg. Inc., Pestigo, WI, USA). After double-sided profiling, each sample was cut into two using a pendulum saw, as above. The sub-samples were oriented either pith-side-up or bark-side-up during the subsequent natural weathering trial. A total of seventy-two deckboard samples each with a final dimension of $32 \times 130 \times 292 \mathrm{~mm}^{3}$ were manufactured. The ends of deckboard samples were coated with an epoxy sealer (Intergard ${ }^{\circledR} 740$, International Paint Singapore Pty Ltd., Jurong, Singapore) to prevent end checking of boards during conditioning and weathering. The decking samples were stored in a conditioning room at $20 \pm 1{ }^{\circ} \mathrm{C}$ and $65 \pm 5 \%$ r.h. for at least three months before the outdoor weathering trial.

Table 1. Geometry of profiles in western larch deckboards.

\begin{tabular}{cccc}
\hline Profile Type $^{\mathbf{1}}$ & Groove Depth (mm) & Groove Radius (mm) & Peak Radius (mm) \\
\hline Flat & - & - & - \\
Rib & 2.0 & 0.16 & 2.4 \\
Short rib & 1.5 & 0.16 & 2.4 \\
Tall rib & 2.5 & 0.15 & 2.2 \\
Ribble & 2.0 & 0.65 & 1.3 \\
Ripple & 2.0 & 1.0 & 1.2 \\
\hline \multicolumn{4}{r}{${ }^{1}$ Number of peaks per 150 mm was 20 for all profiles except flat samples. }
\end{tabular}

Profiled and flat deckboard sub-samples from the same parent western larch board (board 1, 2, 3, 4,5 , or 6 ) were screwed onto separate sub-frames made from preservative-treated $2 \times 4$-dimensional lumber. Each deckboard was spaced $10 \mathrm{~mm}$ apart from adjacent boards and fastened at its four corners onto the weathering rack using hidden galvanized screws $\left(\mathrm{CAMO}^{\circledR}\right.$ fastening system, National Nail Corp. Grand Rapids, MI, USA, http://www.camofasteners.com/). A total of six mini-decks were constructed, each measuring $30 \mathrm{~cm}$ long, $177 \mathrm{~cm}$ wide, and $61 \mathrm{~cm}$ high. In addition, end boards made from preservative-treated lumber measuring $\sim 40 \times 90 \times 300 \mathrm{~mm}^{3}$ were screwed on to the two ends of each rack to prevent the edges of samples at the ends of racks from weathering. The test decks were 
then placed outdoors in Vancouver for seven months from March to October 2019. The deckboard samples were removed from racks and stored in a conditioning room at $20 \pm 1{ }^{\circ} \mathrm{C}$ and $65 \pm 5 \%$ r.h. for two weeks before profilometry measurements. After the weathering trial, samples measuring $15 \times 15 \times 38 \mathrm{~mm}^{3}$ were cut from each of the six parent western larch boards. The basic density of these samples was calculated using their oven dry weight (obtained by oven drying samples at $105^{\circ} \mathrm{C}$ to a constant weight) divided by their water-saturated volume (obtained by Archimedean displacement).

\subsection{Measurement and Imaging of Shelling of Weathered Deckboards}

The shelling of the flat western larch deckboard samples was characterized using a non-contact surface confocal profilometer equipped with a $3 \mathrm{~mm}$ probe (Altisurf $500^{\circledR}$, Altimet, 298 Allée du Larry, 74200, Marin, France) [22]. The profilometer measured the heights of each deckboard sample along a $100 \mathrm{~mm}$ line at three locations; each line was offset approximately $16 \mathrm{~mm}$ from the edges of samples. Height data were extracted from line scans using the software ProfilmOnline (Filmetrics, KLA Co., San Diego, CA, USA). Heights of shelled growth rings were measured from the tip of the latewood projecting from the wood surface to the adjacent earlywood. In addition, a $625 \mathrm{~mm}^{2}$ area on samples was scanned using the confocal profilometer and reconstructed using Altimet Premium (version 6.2) to provide three-dimensional (3D) images of growth rings. Profilometry was also used to image shelling of latewood tips occurring on the peaks of profiled western larch deckboard samples. The number of detached or raised latewood tips at the surface of profiled deckboard samples was counted, and the surfaces of flat and profiled boards were photographed using a Canon EOS 80D digital single lens reflex camera equipped with a Canon EF-S $35 \mathrm{~mm}$ f/2.8 macro lens. End-grain of flat deckboards with shelling were scanned using a desktop scanner (Hewlett-Packard Office Jet 6700, Palo Alto, CA, USA) at 600 dpi resolution, which was sufficient for subsequent image analysis. Scanned images were then examined with the image analysis software ImageJ (version 1.51q) (https://imagej.nih.gov/ij/) to measure growth ring angle to the surface of the corresponding shelled growth ring (Figure 1a). The number of growth rings per $\mathrm{cm}$ on the end grain of deckboard samples was measured using a transparent plastic ruler.

We also imaged shelling in flat Douglas fir, western hemlock, and white spruce deckboards that had been treated with a $1.8 \%$ alkaline copper quaternary (ACQ) preservative and exposed to natural weathering for 18 months. These boards were part of an experimental trial that examined effects of three factors, profile type, wood species (Douglas fir, western hemlock and white spruce) and growth ring orientation (boards with growth rings oriented either bark-side-up or pith-side-up) on the cupping and checking of deckboards during weathering. The materials and methods that were used to prepare and weather these deckboards are described in detail in a recent publication [8]. Flat weathered deckboards with growth rings oriented pith-side-up were selected, and shelled growth rings were imaged using confocal profilometry and macro-photography, as described above.

Scanning electron microscopy was used to examine the interface between latewood and earlywood in shelled growth rings in flat Douglas fir, western hemlock and white spruce deckboards. Samples measuring $15 \times 15 \times 15 \mathrm{~mm}^{3}$ and each containing a shelled growth ring were cut from deckboard samples using a small razor saw (Lee Valley Tools Ltd., Vancouver, BC, Canada, ultra-thin razor saw 60F0310). Samples were dried over silica gel at $20 \pm 1^{\circ} \mathrm{C}$ for $24 \mathrm{~h}$ and reduced in size to $\sim 5 \times 5 \times 8 \mathrm{~mm}^{3}$ using single-edged razor blades (gem surgical carbon steel blades, American Safety Razor Co. Cedar Knolls, NJ, USA) [23]. Samples with either transverse or tangential (weathered) surfaces facing uppermost were glued to separate aluminium stubs using Nylon nail polish as an adhesive. The stubs were sputter coated with an $8 \mathrm{~nm}$ layer of gold and they were then examined using a Zeiss Ultra Plus field emission scanning electron microscope (Carl Zeiss AG, Oberkochen, Germany) at an accelerating voltage of $5 \mathrm{kV}$, working distances of 14.8 to $15.9 \mathrm{~mm}$, and a high vacuum $\left(1.3 \times 10^{-4} \mathrm{~Pa}\right)$. Secondary electron images of samples were obtained and saved as TIF files. 


\subsection{Experimental Design and Statistical Analysis of Data}

Our experiment was designed to examine the effects of surface profiling and growth ring orientation on the checking and cupping of western larch deckboards that were exposed to natural weathering. The experiment was a randomized block design with two fixed factors: (a) Boards with different surface profiles, as defined and described previously, Table 1 [24], including three rib profiles (rib, short rib, and tall rib), and two wavy profiles (ribble and ripple): flat boards acted as a control; (b) growth ring orientation (concave, pith-side-up; and convex, bark-side-up). Six replicate blocks of twelve samples ( 6 profiles $\times 2$ orientations $\times 6$ replicates $=72$ samples) were prepared and exposed to natural weathering. Linear regression was used to examine the relationship between growth ring angle and height $(\mathrm{mm})$ of shelled growth rings in flat western larch boards oriented pith-side-up. Analysis of variance was used to examine the effects of growth ring orientation and profile type on numbers of shelled growth rings in profiled boards. The latter count data was transformed (square root) before final analysis. Statistical computation used the software, Genstat (v. 19). The results are presented graphically and Fisher's least significant difference (LSD) bar $(p<0.05)$ can be used to determine whether differences between individual means are statistically significant [25].

\section{Results}

\subsection{Shelling of Growth Rings in Flat Western Larch Deckboards}

Shelling was clearly evident at the surface of flat western larch deckboards exposed pith-side-up to the weather. The confocal profilometry height map and adjacent matching photographic image in Figure 2 show that shelling of western larch deckboards was due to oblique checking at the interface between latewood and earlywood and the projection of latewood above the deckboard surface, as in Figure 2a,b.

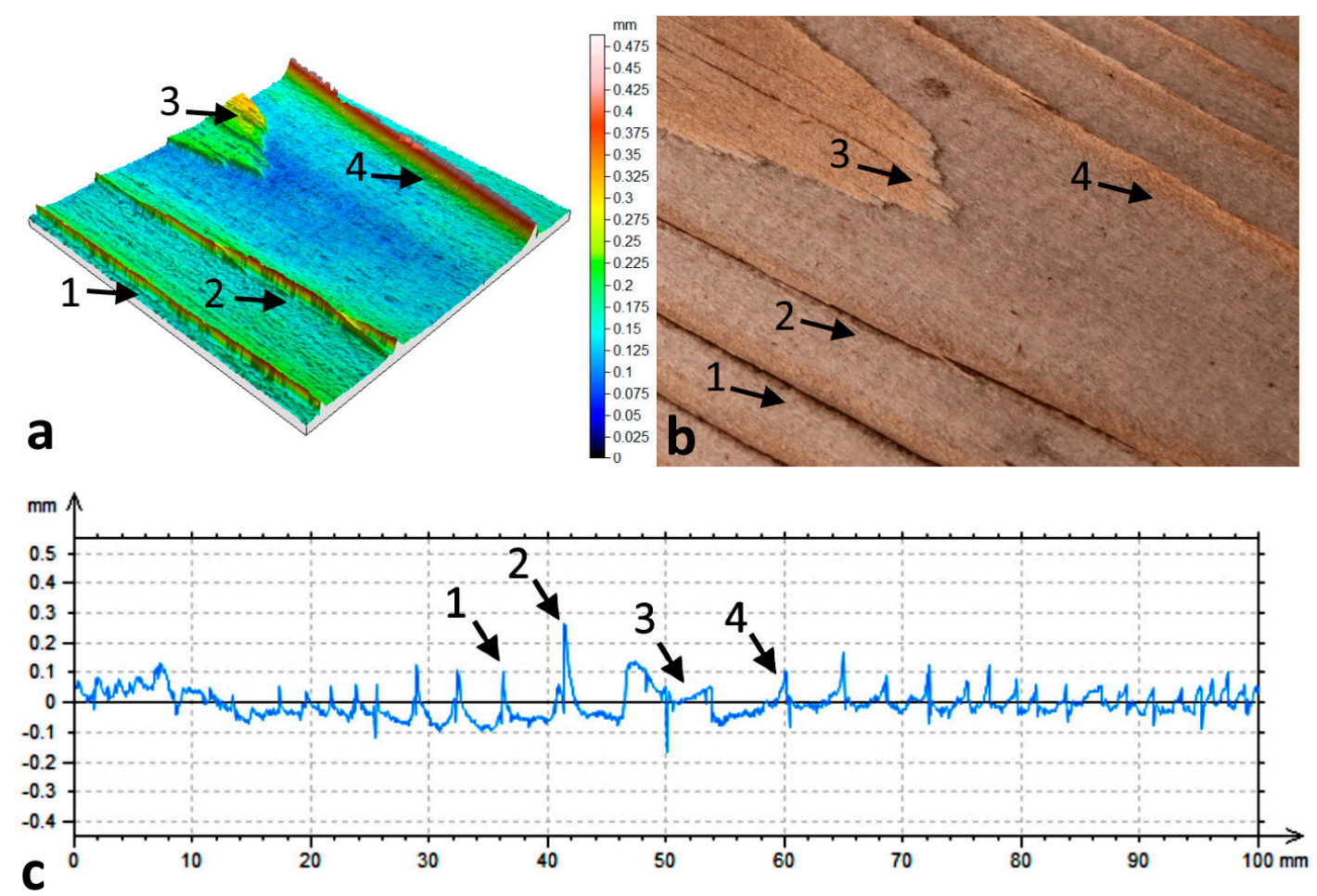

Figure 2. Shelling of growth rings in a flat western larch deckboard oriented pith-side-up and exposed to the weather for 7 months in Vancouver, BC, Canada. Four shelled growth rings including a shelled latewood tip are labelled, 1, 2, 3, and 4: (a) confocal profilometry height map showing four shelled growth rings; (b) photograph of four shelled growth rings matching the height map in Figure 2a; and, (c) confocal profilometry line scan showing the heights of the shelled growth rings in Figure 2a,b. 
The three-dimensional (3D) profilometry height map and line scan of a weathered western larch deckboard with growth rings oriented pith-side-up shows the extent to which latewood projected above the wood surface, Figure 2a,c. For example, the numbered (1,2, and 4) red coloured regions of the profilometry height map in Figure 2a correspond to the similarly numbered latewood bands in growth rings in Figure $2 b$. The heights of latewood bands in Figure 2a and the line scan Figure 2c indicate that one of the latewood bands (number 2) projected approximately $0.3 \mathrm{~mm}$ above adjacent earlywood. The latewood tip in Figure 2a,b (number 3) projected $0.15 \mathrm{~mm}$ above earlywood. The central area of Figure $2 \mathrm{a}, \mathrm{b}$ is where a growth ring is parallel $\left(0^{\circ}\right)$ to the underlying surface. The heights of shelled latewood tend to be greatest in growth rings adjacent to this central region (Figure 2c), and then diminish in height further away from the central part of the deckboard. Latewood separated from the earlywood in the adjacent growth ring (inter-ring failure) rather than from earlywood in the same ring (intra-ring failure).

Table 2 shows profilometry measurements of the heights that shelled growth rings projected above the surface of each of the six western larch deckboard samples oriented pith-side-up and exposed to the weather. This table also includes the density of the parent boards and the numbers of growth rings per $\mathrm{cm}$. The extent to which shelled growth rings projected above the surface of deckboard samples varied between the six boards, but there appeared to be no relationship between wood density and growth ring width and severity of shelling, as in Table 2.

Table 2. Wood properties and shelling of six different flat western larch deckboards oriented pith-side-up and exposed to the weather in Vancouver, BC, Canada for 7 months.

\begin{tabular}{|c|c|c|c|c|}
\hline Board No. & Height Shelling $(\mathrm{mm})^{1}$ & No. Shelled Growth Rings ${ }^{2}$ & Wood Density $\left(\mathrm{g} / \mathrm{cm}^{3}\right)$ & Growth Rings/cm \\
\hline 1 & $0.10(0.16-0.063)$ & $6(36)$ & 0.517 & 9.0 \\
\hline 2 & $0.12(0.31-0.056)$ & $19(37)$ & 0.431 & 5.0 \\
\hline 3 & $0.18(0.48-0.081)$ & $14(30)$ & 0.456 & 6.0 \\
\hline 4 & $0.08(0.21-0.019)$ & $32(55)$ & 0.467 & 6.0 \\
\hline 5 & $0.05(0.07-0.013)$ & $12(54)$ & 0.442 & 7.5 \\
\hline 6 & $0.19(0.52-0.068)$ & $17(47)$ & 0.488 & 8.5 \\
\hline
\end{tabular}

\footnotetext{
${ }^{1}$ Average height of shelled growth rings. Max and min in parentheses; ${ }^{2}$ Total number of growth rings in parentheses.
}

There was an inverse relationship between the height of shelled growth rings and the angle growth rings made to the surface of flat boards oriented pith-side-up, as in Figure 3. In other words, shelled growth rings with a smaller angle to the surface tended to project further from the surface than growth rings that were inclined at a higher angle to the surface. The regression between shelled growth ring height and growth ring angle was very significant $(p<0.001)$, but the correlation coefficient was low $\left(R^{2}=0.327\right)$. This may be caused by our small sample size.

Shelling did not occur at the surface of flat weathered deckboards oriented bark-side-up, although checking was more pronounced at the surface of boards oriented bark-side-up compared to those oriented pith-side-up, Figure 4, in accord with the results of previous studies [5,8]. Many of the checks in boards oriented bark-side-up occurred at the interface of latewood and earlywood (Figure 4), but did not cause growth rings to project from the surface of the wood, as was observed in boards oriented pith-side-up. Latewood was raised slightly above the surface of adjacent earlywood possibly due to springback or differential swelling of latewood and/or increased degradation and erosion of earlywood compared to latewood $[6,26]$. 


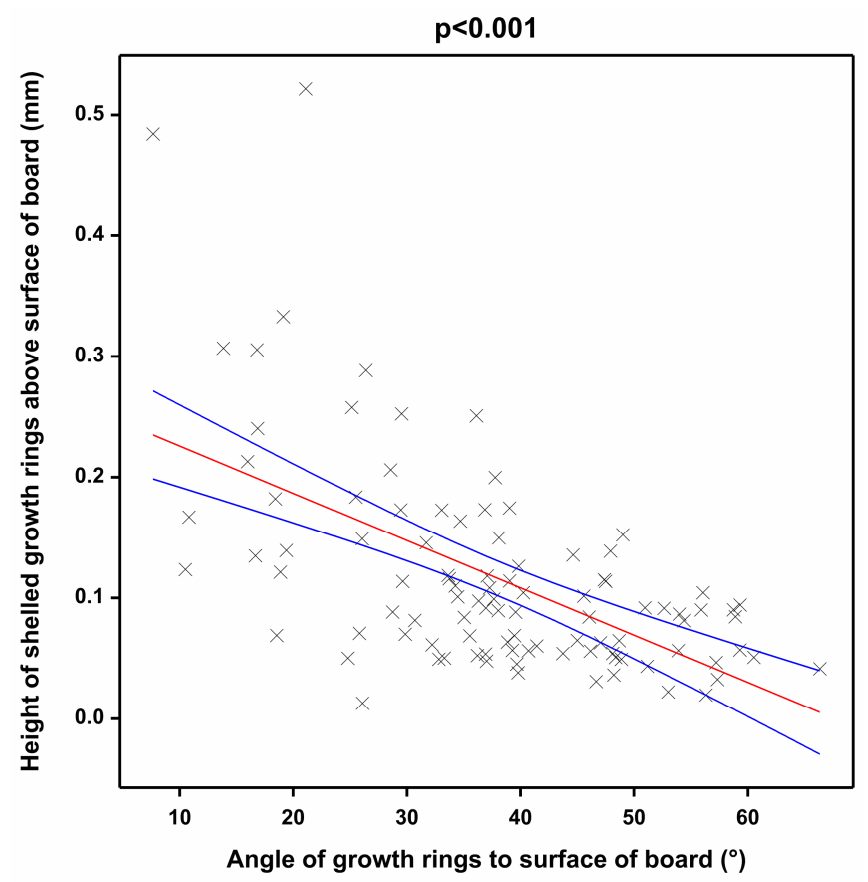

Figure 3. Linear regression (red line) of heights of latewood in shelled growth rings versus growth ring angle in flat western larch deckboards oriented pith-side-up and exposed to the weather for seven months in Vancouver, Canada; regression includes 95\% confidence intervals (blue-lines).

a
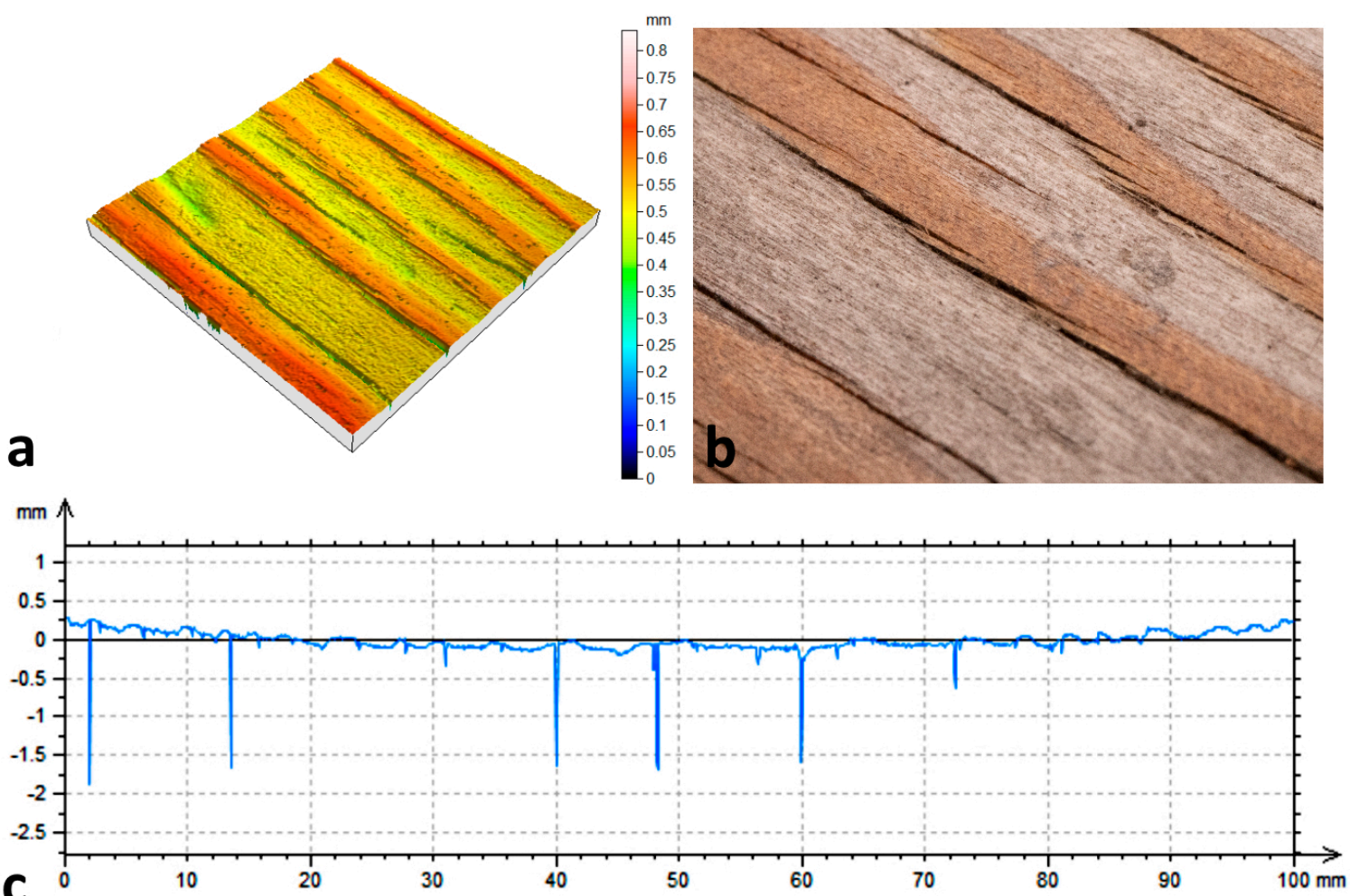

Figure 4. Appearance of a western larch deckboard with growth rings oriented bark-side-up and exposed to the weather for 7 months in Vancouver, Canada: (a) confocal profilometry height map showing surface checking and roughening of the wood surface; (b) photograph matching the image in Figure 4a; and, (c) confocal profilometry line scan showing variation in height of images in Figure 4a,b. 


\subsection{Shelling of Growth Rings in Flat ACQ-Treated Douglas Fir, Western Hemlock and White} Spruce Deckboards

Confocal profilometry imaging of flat ACQ-treated western hemlock, white spruce, and Douglas fir deckboards oriented pith-side-up and exposed to the weather for 18 months showed that shelling in these species was due to inter-ring delamination of growth rings and projection of latewood above adjacent earlywood, as in Figure 5. In western hemlock and white spruce, latewood in shelled growth rings projected over $1 \mathrm{~mm}$ above the surface, and splitting of delaminated latewood occurred in western hemlock creating sharp splinters. The delamination of growth rings and projection of latewood above weathered deckboard surfaces was more pronounced in western hemlock and white spruce than in Douglas fir boards.
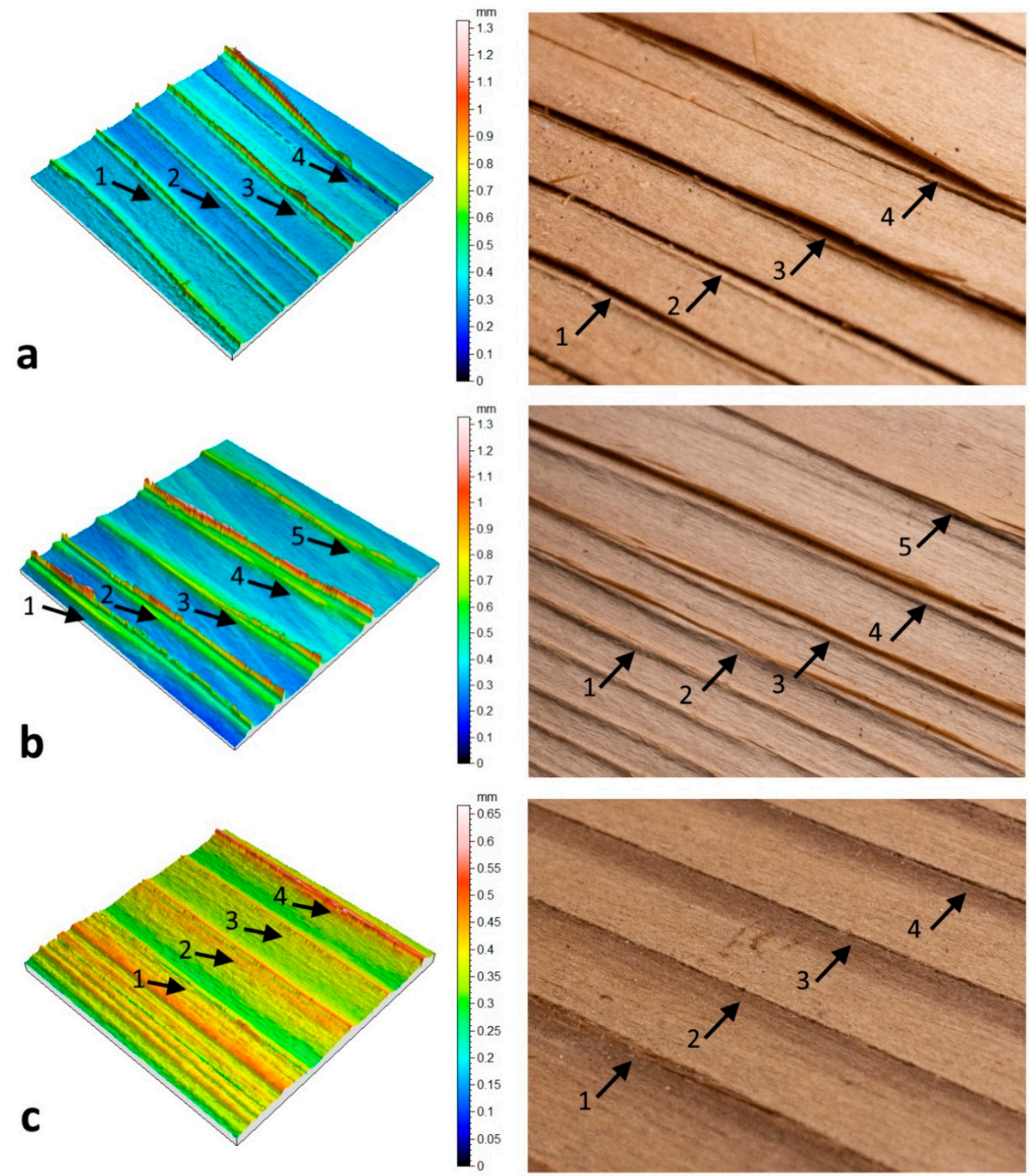

Figure 5. Confocal profilometry height maps showing shelling of growth rings in alkaline copper quaternary (ACQ) treated (a) western hemlock, (b) white spruce, and (c) Douglas fir deckboards with growth rings oriented pith-side-up and exposed to the weather for 18 months in Vancouver, BC, Canada. 
Scanning electron microscopy was used to examine the interface between latewood and earlywood in shelled growth rings in Douglas fir, western hemlock, and white spruce deckboards, as in Figure 6. Images of shelled growth rings in all three species show a check between thicker-walled latewood cells and thinner-walled earlywood cells. In western hemlock, there was evidence that delamination of growth rings resulted from fracture of thin walled earlywood tracheids, as shown in Figure 6d,f. All three species showed evidence of photodegradation, for example, pit micro-checking (arrowed in Figure $6 \mathrm{a}, \mathrm{c}$ ) and colonization of the wood surface by mould fungi (arrowed in Figure 6d).
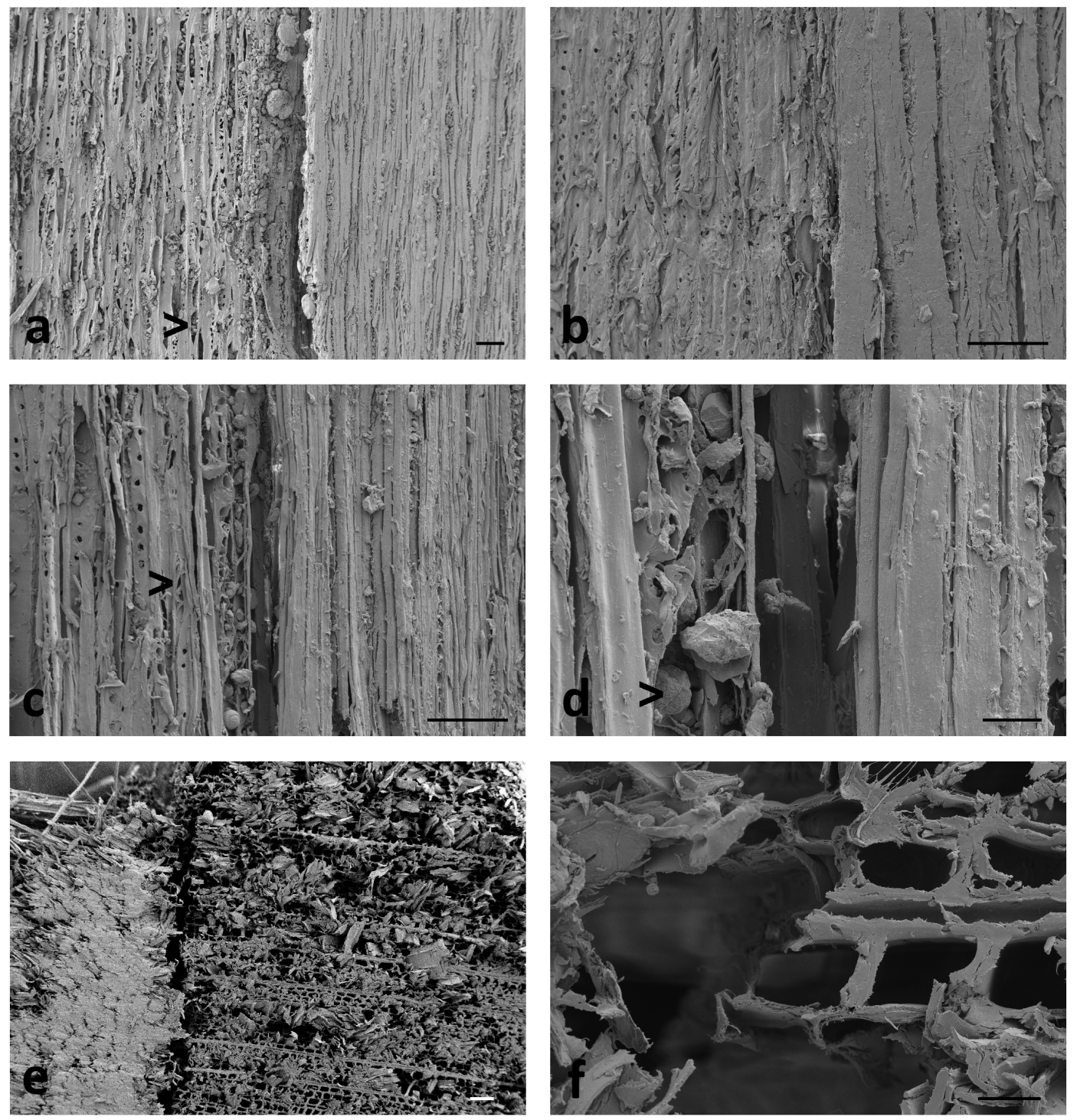

Figure 6. Scanning electron microscopy images of shelled growth rings in small samples from flat ACQ-treated Douglas fir, white spruce and western hemlock deckboards with growth rings oriented pith-side-up and exposed to the weather for 18 months in Vancouver, Canada: (a) Douglas fir sample showing separation of latewood (right) from earlywood. Note pit micro-checking in earlywood (arrowed bottom left); (b) white spruce sample showing separation of latewood (right) from earlywood; (c) western hemlock sample showing separation of latewood (right) from earlywood. Note pit micro-checking in earlywood (arrowed centre left); (d) western hemlock sample showing failure of earlywood cell wall (centre) where latewood separates from earlywood. Note mould in earlywood (arrowed bottom left); (e) a cross section through a shelled growth ring in western hemlock showing separation of latewood (left) from earlywood; and, (f) a cross section through a shelled growth ring in western hemlock showing failure of earlywood cell walls where latewood (left) separates from earlywood. Scale bars $(\mathbf{a}-\mathbf{c}, \mathbf{e})=100 \mu \mathrm{m} ;(\mathbf{d}, \mathbf{f})=20 \mu \mathrm{m}$. 


\subsection{Shelling of Growth Rings in Profiled Western Larch Deckboards}

Weathering caused the separation of latewood and earlywood in some profile peaks in profiled deckboards with growth rings oriented pith-side-up. The separation of growth rings created lanceolate-shaped slivers (tips) of latewood that projected above the surface of deckboards, as in Figure 7. Figure 7a,c shows the extent to which the slivers projected above the rib of a profiled board. Shelling at the edges of growth rings was less obvious in profiled deckboards than in flat boards, even though latewood clearly separated from earlywood Figure $7 \mathrm{~b}$.

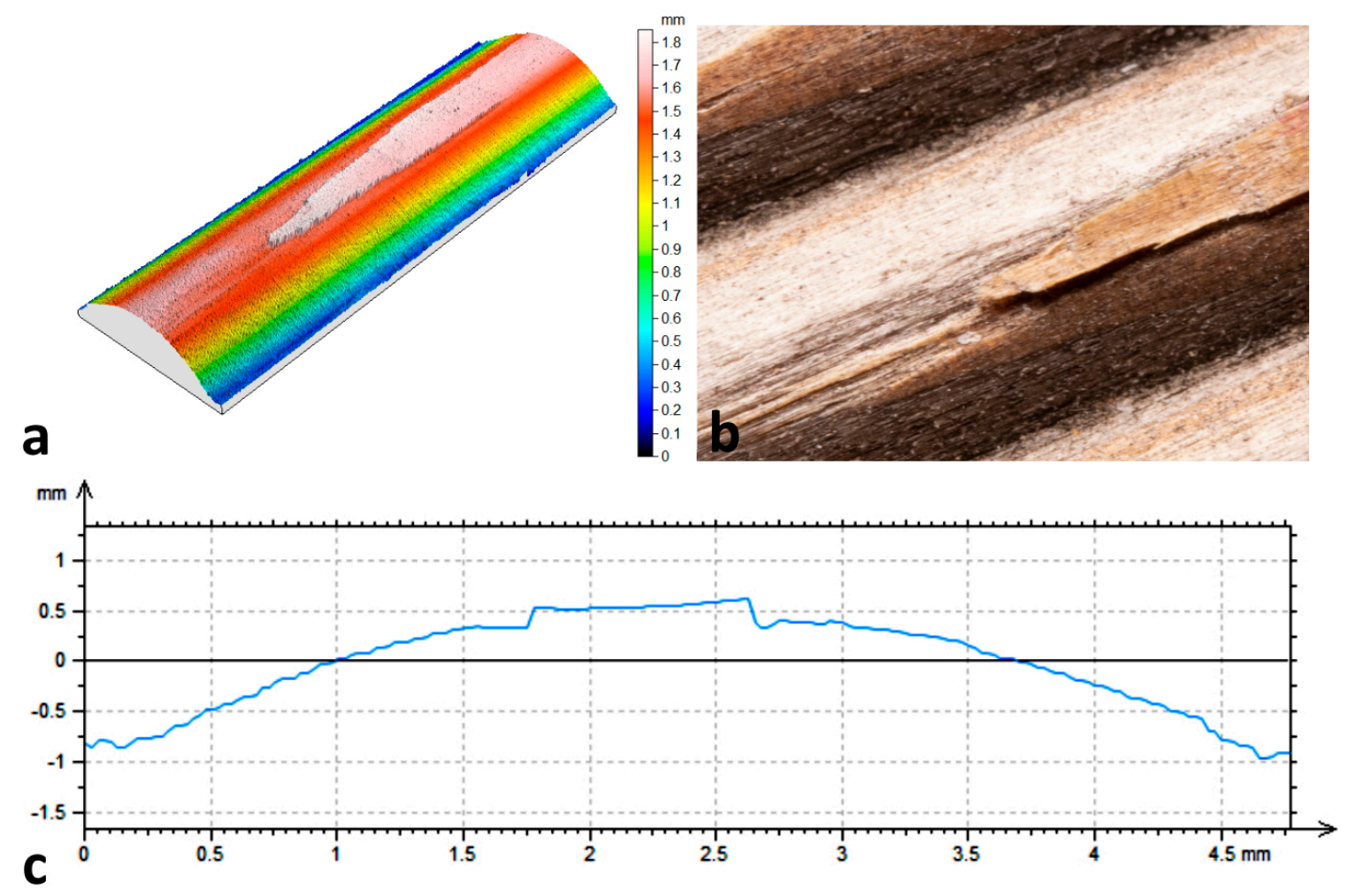

Figure 7. Shelling of a growth ring tip on the peak of a profiled (rib) western larch deckboard with growth rings oriented pith-side-up and exposed to the weather for seven months in Vancouver, Canada: (a) confocal profilometry height map of a shelled latewood tip; (b) photograph of a shelled latewood tip matching the image in Figure 7a; and, (c) confocal profilometry line trace showing variation in height of the latewood tip in Figure $7 \mathrm{~b}$.

Growth rings rarely separated (shelled) at the interface of latewood and earlywood at the peaks of profiled deckboards with growth rings oriented bark-side-up. However, latewood tips were slightly raised above the surface of adjacent earlywood, as can be seen in the profilometry height map and photograph in Figure 8. The extent to which latewood was raised above the surface of the adjacent earlywood was much smaller than that of shelled latewood tips in profiled boards oriented pith-side-up (compare Figures 7c and 8c). 


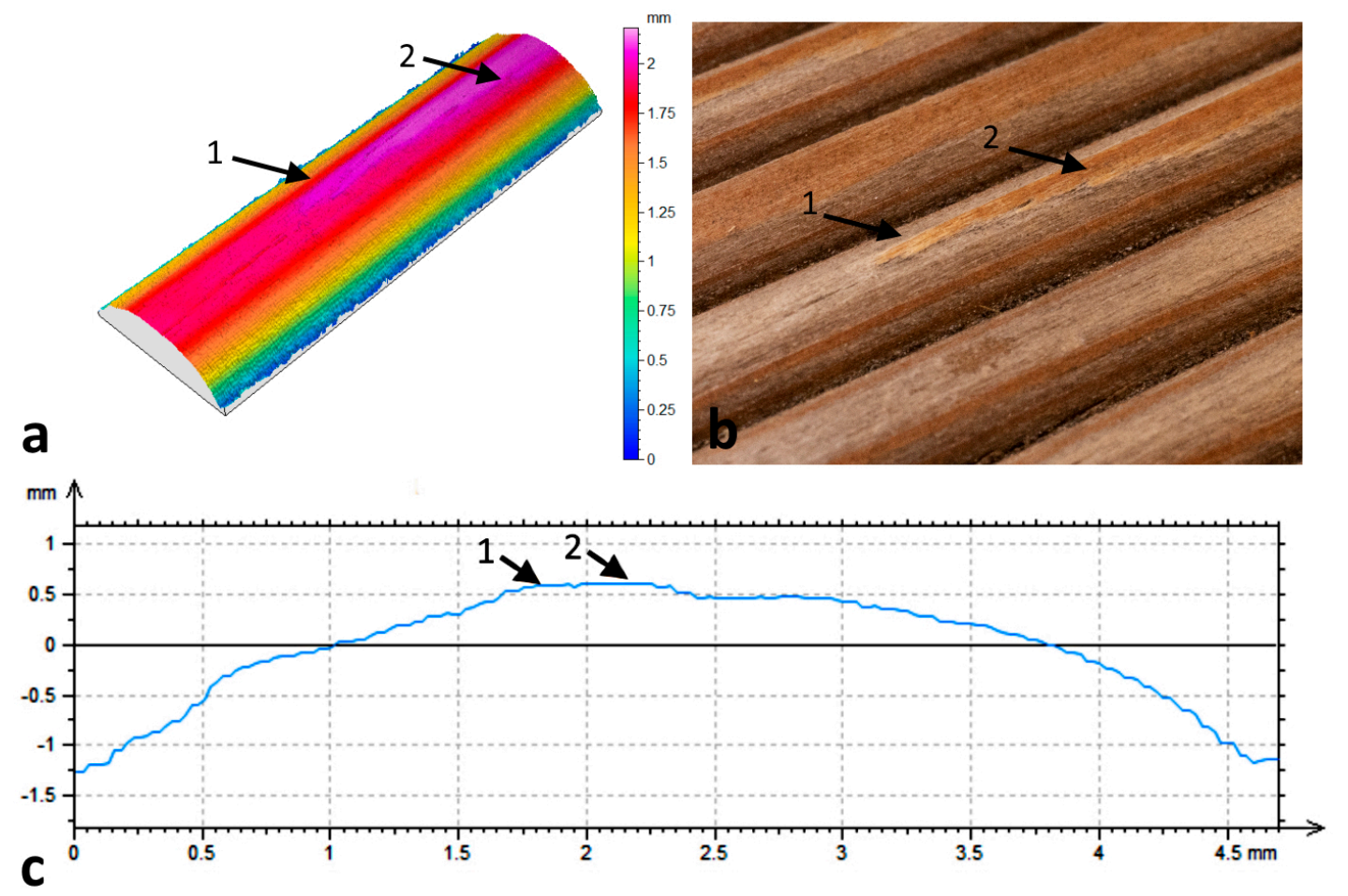

Figure 8. Tip of a growth ring raised above the peak of a profiled (short rib) western larch deckboard with growth rings oriented bark-side-up and exposed to the weather for seven months in Vancouver, Canada: (a) confocal profilometry height map of a latewood tip; (b) photograph of a latewood tip matching the image in Figure 8a; and, (c) confocal profilometry line trace showing variation in height of the arrowed rib in Figure $8 b$.

We counted the number of latewood tips that visibly projected above the surface of profile peaks in boards with different growth ring orientations (pith-side-up and bark-side-up) and profile geometries (rib, short rib, tall rib, ribble, and ripple). Analysis of variance indicated that the number of visible latewood tips at the surface of profiled and weathered deckboards oriented pith-side-up was significantly $(p<0.001)$ greater than that of similarly weathered boards oriented bark-side-up, as in Figure 9.

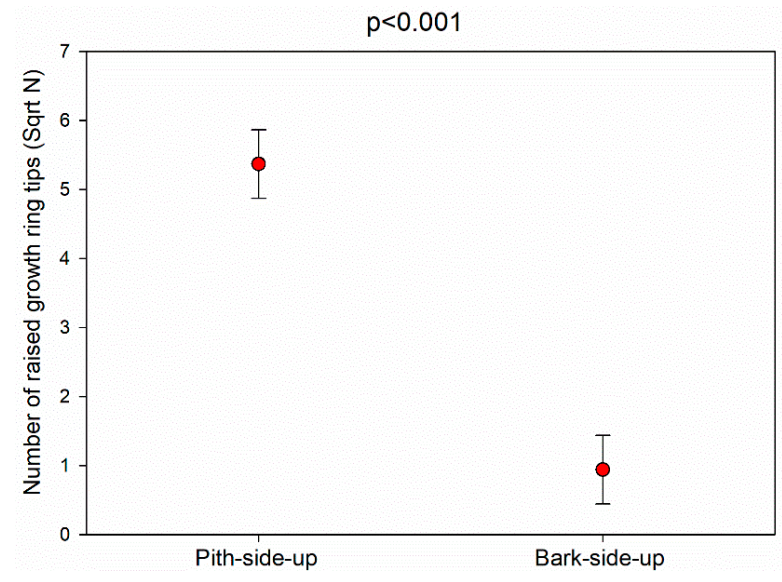

Figure 9. Effects of growth ring orientation on the numbers of latewood tips that projected above the surface of profiled western larch deckboards exposed to natural weathering for seven months in Vancouver, Canada. The results are averaged across boards with different profiles because there was no significant $(p>0.05)$ interaction of growth ring orientation and profile type on numbers of raised latewood tips. Error bars = Least significant difference, $p<0.05$. 
There was a small, but statistically significant $(p=0.036)$ effect of profile type (rib, ribble, and ripple, etc.) on the number of latewood tips that visibly projected above the surface of peaks in profiled boards, Figure 10, but the interaction of growth ring orientation $x$ profile type was not significant $(p>0.05)$. Boards with a wavy ribble profile had significantly $(p<0.05)$ fewer visible latewood tips when compared to other profiled boards, except for boards with a wavy ripple profile (Figure 10).

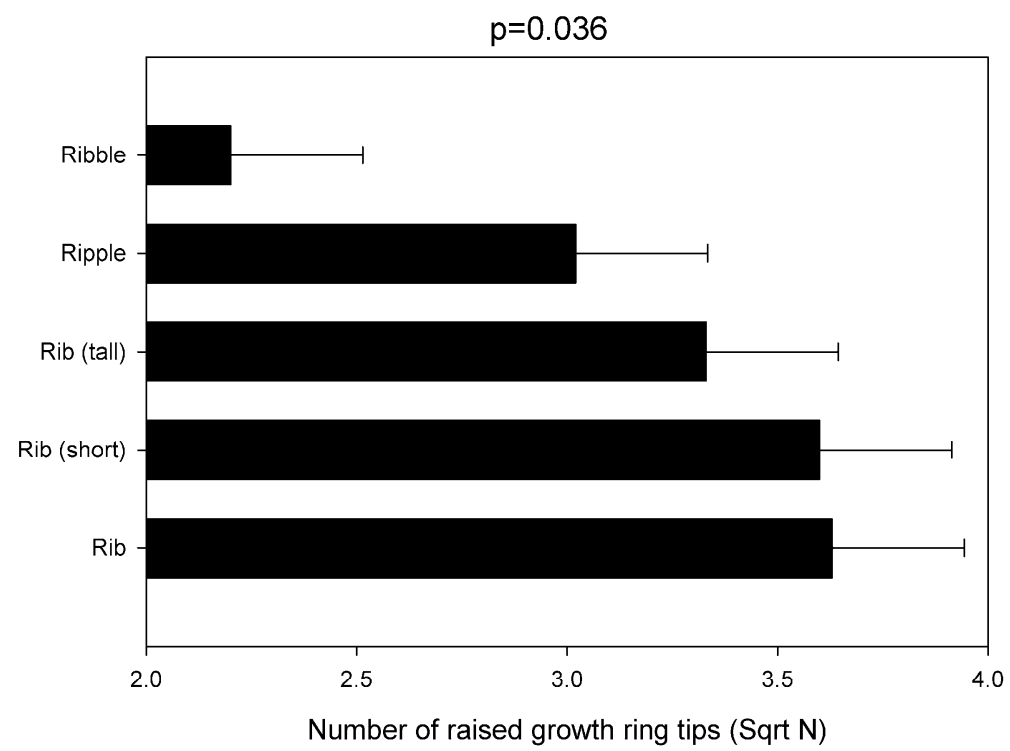

Figure 10. Effects of profile type on the numbers of latewood tips that projected above the surface of profiled western larch deckboards exposed to natural weathering for seven months in Vancouver, Canada. Results are averaged across boards with different growth ring orientations because there was no significant $(p>0.05)$ interaction of growth ring orientation and profile type on numbers of raised latewood tips. Error bars = Least significant difference, $p<0.05$.

\section{Discussion}

Our results support our hypothesis that confocal profilometry can quantify shelling at the surface of weathered deckboards, but the methodology is not completely straight-forward. The surfaces of weathered deckboards contain features that span various scales. For example, in the Z-direction (height), wood cell walls and raised grain can project 10 to $50 \mu \mathrm{m}$ from wood surfaces, respectively $[16,17,27]$. Weathering can lead to millimetres of erosion of wood [6], and these variable perturbations in the vertical heights of deckboard surfaces can be superimposed upon more structured surface features, such as machined profiles [21]. These multiscale features of wood surfaces have all been quantified using confocal profilometry, but probes with higher sensitivity and smaller sampling areas are required for features in the micron range as compared to those in millimeter range [16-19,27,28]. Hence, selective sampling of areas of deckboard surfaces showing shelling was required, particularly for profiled boards, to extract information on the maximum height of shelled growth rings, which was the parameter of greatest practical interest. When we took this approach, confocal profilometry was able to reveal a negative correlation between growth ring angle and severity of shelling in flat-sawn western larch boards oriented pith-side-up, and confirm previous suggestions in the literature that flat deckboards oriented pith-side-up are more susceptible to shelling than boards oriented bark-side-up [7,9-11]. Our results also accord with results of Davis, cited in Koehler that wood density and width of annual ring appear to have no effect on shelling, and also his suggestion that wood species differ in their susceptibility to shelling $[9,10]$. Further research is needed to fully explore species differences in susceptibility to shelling, and the influence of other factors on shelling, for example, contrast in density between earlywood and latewood [10], and the application of water-repellent finishes [29]. 
We showed, for the first time, that shelling occurs at the surface of profiled deckboards exposed to the weather, and we described the morphology of shelling that developed in profiled boards. The shelling of profiled boards was due to the separation of latewood tips on the peaks of profiles, and our results suggested that boards with a wavy profile were less susceptible to shelling than boards with rib profiles. One possible explanation for this observation is that boards with wavy profiles have narrower peaks (1.2 to $1.3 \mathrm{~mm}$, Table 1), which could reduce the possibility of latewood tips occurring on the peaks of profiles, and subsequently separating from earlywood, when compared to rib profiles that have wider peaks ( 2.2 to $2.4 \mathrm{~mm}$, Table 1). Shelling of profiled boards was more pronounced in deckboards oriented pith-side-up compared to those oriented bark-side-up, in accord with our observations of the shelling of flat (unprofiled) boards.

Our observations confirm that shelling at the surface of boards oriented pith-side-up occurs due to fracture at the boundary between the latewood of one growth ring and the earlywood of the subsequent growth ring $[9,10]$. It is at this point that there is the greatest contrast in density between latewood and earlywood tracheids [30] and, hence, the potential for maximum stress concentration due to differential swelling and shrinkage of latewood and earlywood. These stresses are responsible for delamination at growth ring boundaries according to Koehler [9]. Intra-wall rather than interfacial fracture was observed in earlywood cell walls at the growth ring boundary of a shelled growth ring in western hemlock. We suggest that fracture at the latewood-earlywood boundary allows for unrestrained swelling of latewood, causing it to curl away from the wood surface in the same direction as the curvature of growth rings. We did not observe similar shelling in boards oriented bark-side-up although latewood projected slightly above wood surfaces, possibly due to springback or differential swelling of latewood and/or increased erosion of adjacent earlywood. Checking occurred at the interface between latewood and earlywood in boards oriented bark-side-up, but extended radially into wood, rather than propagating via the boundary between latewood and earlywood. The mechanisms that are responsible for the pronounced difference in shelling of boards oriented pith-side-up versus those oriented bark-side-up are well explained by Koehler [9] and in an anonymous publication by the U.S. Forest Products Laboratory that draws upon Koehler's work [10]. Our observations accord with Koehler's explanations [9] for the effects of growth ring orientation on the shelling of flat-sawn boards.

Shelling is a serious defect in wood species with a pronounced contrast between earlywood and latewood density $[9,10]$. Shelling of western larch wood was mentioned by Johnson and Bradner [12], who stated that it is objectionable because of danger from splinters, and its potential to create a tripping hazard. Our results indicate that the simplest way of avoiding the occurrence of shelling at the surface of flat western larch deckboards, is to orient boards bark-side-up rather than pith-side-up. Shelling can also be minimized, as others have pointed out, by machining boards with sharp cutter knives $[9,10]$, and using a water-repellent treatment to reduce surface changes in wood moisture content [29]. All of these recommendations are also relevant to profiled larch deckboards, which developed shelling when exposed to the weather. An additional measure that would help reduce shelling of profiled larch deckboards is to use a wavy rather than a rib profile. Profiled deckboards should be profiled on both sides to produce a balanced board that is less susceptible to cupping [8]. A profile on the pith-side of boards that is different to that on the bark-side would make it easier to orient deckboards correctly, although the sub-surface profile would need to be able to achieve its desired aim of reducing cupping. Further research is needed to develop such sub-surface profiles, which could include saw kerfs or grooving that are employed on the undersides of flooring and some commercial deckboards [21,31].

\section{Conclusions}

Non-contact confocal profilometry was able to quantify shelling of growth rings at the surface of flat and profiled softwood deckboards that were exposed to natural weathering. Using this technique, we have shown how the orientation of growth rings and the angle growth rings make to wood surfaces influences the severity of shelling in flat western larch deckboards exposed to natural weathering. We also show that profilometry can be used to quantify shelling in other wood species and suggest 
that it can provide additional insights into how the properties of wood or treatments, such as coatings and water repellents, influence shelling. Our results confirm that shelling occurs due to inter-ring delamination in deckboards with growth rings oriented pith-side-up. We show, for the first time, that shelling occurs at the surface of profiled deckboards oriented pith-side-up. We conclude that the shelling of flat and profiled boards can be reduced by orienting deckboards bark-side-up and, in the case of profiled boards, using a wavy profile rather than a hemispherical rib profile.

Author Contributions: L.H.L. and P.D.E. conceived and designed the experiments; L.H.L. performed all experimental work, except for scanning electron microscopy (P.D.E.). P.D.E. analyzed all data and wrote the first draft of the paper. Both authors discussed and commented on the results and contributed to the final submitted manuscript. All authors have read and agree to the published version of the manuscript.

Funding: This research was funded by Natural Science and Engineering Research Council of Canada (NSERC) Collaborative Research and Development Grant (CRDPJ 485007-15).

Acknowledgments: We thank Steve Brown, Jarett Pereboom, Terry Cunning, Arne Flaten, Jeff Hunt, Ken Johnstone Jr. and Dan Price from Tolko for a special order of western larch lumber; Brandon Chan, Kenneth J. Cheng, Pablo Chung, Lawrence Gunther, Sina Heshmati, Joseph Doh Wook Kim and Mohammad Sadegh Mazloomi from UBC for helping to machine and characterize deckboard samples; Hua Chen and Frank Brink of the Centre for Advanced Microscopy at The Australian National University (ANU) for assistance with scanning electron microscopy; Canadian Foundation for Innovation, BC Knowledge Development Fund, FPInnovations and Tolko industries for in-kind support. P.D.E. thanks Viance, Tolko, FPInnovations, Faculty of Forestry (UBC) and the Government of British Columbia for their support of his BC Leadership Chair at the University of British Columbia, and The Australian National University (ANU) for an Honorary Professorship in the Department of Applied Mathematics, Research School of Physics at the ANU.

Conflicts of Interest: The authors declare no conflict of interest, and none of the individuals or organizations acknowledged above were involved in the design of our experiment, collection, and interpretation of data or the writing of this paper.

\section{References}

1. Feist, W.C.; Hon, D.N.S. Chemistry of weathering and protection. In The Chemistry of Solid Wood; Advances in Chemistry Series; Rowell, R.M., Ed.; American Chemical Society: Washington, DC, USA, 1984; Volume 207, Chapter 11; pp. 401-405.

2. Lie, S.K.; Vestøl, G.I.; Høibø, O.; Gobakken, L.R. Visual appearance of unpainted wood: Mould coverage, lightness and uniformity. Int. Wood Prod. J. 2019, 10, 9-15. [CrossRef]

3. Christy, A.G.; Senden, T.J.; Evans, P.D. Automated measurement of checks at wood surfaces. Measurement 2005, 37, 109-118. [CrossRef]

4. Schniewind, A.P. Mechanism of check formation. For. Prod. J. 1963, 13, 475-480.

5. Yata, S. Occurrence of drying checks in softwood during outdoor exposure. In High-Performance Utilization of Wood for Outdoor Uses; Imamura, Y., Ed.; Wood Research Institute, Kyoto University: Kyoto, Japan, 2001; pp. 65-70.

6. Williams, R.S.; Knaebe, M.T.; Feist, W.C. Erosion rates of wood during natural weathering: Part II Earlywood and latewood erosion rates. Wood Fiber Sci. 2001, 33, 43-49.

7. Williams, S.; Knaebe, M. The Bark Side/Pith Side Debate. The Finish Line; U.S. Forest Service, Forest Products Laboratory: Madison, WI, USA, 1995; pp. 1-2.

8. Heshmati, S.; Leung, L.H.; Mazloomi, M.S.; Kim, J.D.W.; Evans, P.D. Technical note: Positive effects of double-sided profiling on the cupping and checking of ACQ-treated Douglas fir, western hemlock, and white spruce deckboards exposed to natural weathering. Wood Fiber Sci. 2020, 52, 243-253. [CrossRef]

9. Koehler, A. Raised grain-Its causes and prevention. Southern Lumberman. 1929, 137, 210M-210O.

10. Anonymous. Raised, Loosened, Torn, Chipped, and Fuzzy Grain in Lumber; FPL-099; U.S. Forest Service, Forest Products Laboratory: Madison, WI, USA, 1965; pp. 1-15.

11. Williams, S.; Knaebe, M. The finish line: Practical facts on wood finishing from FPL. Am. Paint Coat. J. Conv. Dly. 1997, 26.

12. Johnson, R.P.A.; Bradner, M.I. Properties of Western Larch and Their Relation to Uses of the Wood; Technical Bulletin 282; United States Department of Agriculture: Washington, DC, USA, 1932; pp. 1-93.

13. Kavanaugh, C. Vinyl Siding Tops Cladding List for 25 Years. Plastics News. July 2019. Available online: https://www.plasticsnews.com/news/vinyl-siding-tops-cladding-list-25-years (accessed on 17 June 2020). 
14. Kavanaugh, C. Composite Decking Making Market Gains. Plastics News. July 2019. Available online: https://www.plasticsnews.com/news/composite-decking-making-market-gains (accessed on 17 June 2020).

15. Nakamura, G.-I.; Takachio, H. An experiment on the roughness and stability of sanded surface. Mokuzai Gakkaishi 1961, 7, 41-45.

16. Landry, V.; Blanchet, P.; Cormier, L.M. Water-Based and solvent-based stains: Impact on the grain raising in yellow birch. Bioresources 2013, 8, 1997-2009. [CrossRef]

17. Evans, P.D.; Cullis, I.; Kim, J.D.W.; Leung, L.H.; Hazneza, S.; Heady, R.D. Microstructure and mechanism of grain raising in wood. Coatings 2017, 7, 135. [CrossRef]

18. Singh, A.; Dawson, B.; Turner, J.; Rickard, C. Anatomical Explanation for Grain Raising in Machined Radiata Boards; Wood Processing Newsletter 41; Scion: Rotorua, New Zealand, 2008; pp. 3-6.

19. Dawson, B.S.W.; Singh, A.P.; Ward, J.; Smolic, T.; Singh, A.; Hands, K.D. Texture of wooden surfaces before and after coating. Surf. Coat. Aust. 2006, 43, 14-18.

20. Böttcher, P. Einfluß verschiedenartiger oberflächenprofilierungen an holz auf die veränderung der wetterbeständigkeit. Holz Roh Werkst. 1977, 35, 247-251. [CrossRef]

21. Cheng, K.J.; Evans, P.D. A note on the surface topography of profiled wood decking. Aust. For. J. 2016, 79, 147-152. [CrossRef]

22. Jamali, A.; Evans, P.D. Plasma treatment reduced the discoloration of an acrylic coating on hot-oil modified wood exposed to natural weathering. Coatings 2020, 10, 248. [CrossRef]

23. Heady, R.D.; Banks, J.G.; Evans, P.D. Wood anatomy of Wollemi pine (Wollemia nobilis, Araucariaceae). IAWA J. 2002, 23, 339-357. [CrossRef]

24. Cheng, K.J.; Evans, P.D. Manufacture of profiled amabilis fir deckboards with reduced susceptibility to surface checking. J. Manuf. Mater. Process. 2018, 2, 7. [CrossRef]

25. Williams, L.J.; Hervé, A. Fisher's least significant difference (LSD) test. In Encyclopedia of Research Design; Salkind, N., Ed.; SAGE: Thousand Oaks, CA, USA, 2010; p. 6.

26. Kataoka, Y.; Kiguchi, M.; Fujiwara, T.; Evans, P.D. The effects of within-species and between-species variation in wood density on the photodegradation depth profiles of sugi (Cryptomeria japonica) and hinoki (Chamaecyparis obtusa). J. Wood Sci. 2005, 51, 531-536. [CrossRef]

27. Jamali, A.; Evans, P.D. Etching of wood surfaces by glow discharge plasma. Wood Sci. Technol. 2011, 45, 169-182. [CrossRef]

28. Hazneza, S.; Evans, P.D. End-Grain erosion of Douglas fir wood during natural weathering. Int. Wood Prod. J. 2016, 7, 3-11. [CrossRef]

29. Schuttner, S. Building and Designing Decks; The Taunton Press Inc.: Newtown, CT, USA, 1998; p. 164.

30. Björklund, J.; Seftigen, K.; Schweingruber, F.; Fonti, P.; von Arx, G.; Bryukhanova, M.V.; Cuny, H.E.; Carrer, M.; Castagneri, D.; Frank, D.C. Cell size and wall dimensions drive distinct variability of earlywood and latewood density in Northern Hemisphere conifers. New Phytol. 2017, 216, 728-740. [CrossRef] [PubMed]

31. Nystrom, R. Board for Use in Constructing a Flooring Surface. U.S. Patent 5,474,831, 12 December 1995.

(C) 2020 by the authors. Licensee MDPI, Basel, Switzerland. This article is an open access article distributed under the terms and conditions of the Creative Commons Attribution (CC BY) license (http://creativecommons.org/licenses/by/4.0/). 